\title{
ON THE IDEOLOGISATION OF ALBANIAN EDUCATION IN THE 6OS OF THE XX CENTURY
}

\author{
Dr. Ilir Sallata \\ Faculty of Education \\ University "Aleksander Moisiu" \\ Durres, Albania \\ il_ir@hotmail.com
}

\begin{abstract}
This paper presents a general picture of the situation in the Albanian education system during the second half of the 60's. Ideologisation and politicization of the society in Albania, dictated by the conditions, circumstances and aims of the Albanian communist leadership, in the context of revolutionizing the life of the country, and it affected the entire education system. Albanian educational institutions would now be designed upon a new philosophy. The changes would include all school categories, basic documentation, plans, curricula and textbooks, which would be subject to total "revolution" and "clearing". The triangle "education - productive work - physical and military education" influenced by the Marxist-Leninist ideological axis would be the basis of the whole teaching process. Extreme ideology and politicization would penetrate in all the areas of the Albanian education system.

During the research work of the given case study, a qualitative method was generally applied by conducting a collective descriptive, explanatory and evaluative research: based mostly on historical facts and literature analysis.
\end{abstract}

Keywords: national education, communism in Albania, ideologisation, revolutionization Humanities

\section{Introduction}

With the establishment of the communist regime in Albania, the education system underwent many changes. Oriented by the Soviet model, the ideologizing and politicization of all areas of the education system began to gradually increase.

Despite the achievements until the early 1960s, mainly in terms of massification, the leadership of the Albanian Labor Party (ALP) realized that education did not respond properly to its political goals and mission of the new era that the country had entered, where the school was to embody the Marxist worldview. ${ }^{1}$

In this context, the spirit of ideology permeated the main spheres of the life of our country.

In the spectrum of this revolutionization was the line of communist education, which was propagated as a movement aimed at emancipating society from traditional customs and practices, inherited from the past. The basic purpose of communist education was to produce a large mass of people, whether workers or intellectuals, who would be used to build socialism, but above all they had to have a "socialist conscience". ${ }^{2}$

Enver Hoxha defined the rooting of socialist ideology and the uprooting of old ideologies, as the decisive factor for solving the problems related to the construction of socialism in the country.

At the meeting of the Political Bureau of the Central Committee of the ALP, E. Hoxha demanded the party and state structures to work for strengthening the importance of school with that of life. Regarding the curricula and plans, they had to focus on strengthening and raising the theoretical level. Linking theory with practice and introducing the element of polytechnic education. ${ }^{3}$

Thus, the new plans and programs in the subject of history provided more complete knowledge about the historical periods as well as in order to increase the political background of the Party of Labour of Albania (PLA), the topics with events of the period of the new history were given priority. Also through the program of this course was aimed at strengthening atheistic-scientific knowledge, e.g. topics such as "The reactionary role of the Christian church in the XI-XIII centuries", "Giordano Bruno and Galileo Galilei", "The struggle of the French Enlightenment against

${ }^{1}$ Historia e Popullit Shqiptar, vëllimi IV, Group of authors, Toena, Tiranë: 2008, p.288

${ }^{2}$ Alfred Uçi, Roli dhe rëndësia e kritikës dhe autokritikës, the magazine Rruga e Partisë, no.2, Tiranë: february 1955, p.27

${ }^{3}$ Enver Hoxha, Vepra 18, 8 Nëntori, Tiranë: 1980, p.138 
religion and the church". In particular, the main aim was the strengthening of the knowledge that ensured the ideological formation of students. ${ }^{4}$

The political subjects in both cycles of general education were especially strengthened. In grade VIII was introduced the new subject "Civic Education" through which students would receive the first knowledge on social and state building for the Republic of Albania and the basic requirements of communist morality. In the upper secondary schools this knowledge was further elaborated with the subject "Introduction to political knowledge". 5

The IV Congress of the PLA of the year 1961, would emphasize the need to take quick measures that would enable the start of the process. According to the orientation of this congress, the reorganization of the school would establish, first of all, its closer links with production, raising the quality level and the better progress of students, expanding the school network of all categories and in particular, gradual transition from 7-year compulsory education to 8-year education. ${ }^{6}$

In the Marxist concept, youth education issues represented an important political and social problem, centered and run by the communist party. Through the draft legislation, the measures taken, the decisions of the state bodies and the political-state organizations, the foundations of a comprehensive system for the communist education of the new generation were created. ${ }^{7}$

The totalitarian efforts of the state were focused on building and consolidating a broad system for indoctrination with communist ideology and increasing pressure to bring it under its full control. ${ }^{8}$

In this context, a great deal of work was carried out on the political education and re-education of teachers with the communist ideology. A variety of forms similar to those used in other totalitarian countries continued to be applied, such as seminars, lectures, regular political forms, conferences, etc. In addition to the press, radio, publication of classic works of Marxism-Leninism, the attention of state and party structures focused on perfecting and consolidating the system set up to increase its efficiency. and political with school-based organizations such as the Youth and Teachers' Professional Associations. ${ }^{9}$

In November 1966, the V Congress of the PLA was held, defining as its main task the deepening of the socialist revolution in all fields and as a priority link the ideological revolution and the Class conflict. ${ }^{10}$

The Albanian school would already be designed with a new physiognomy. On March 7, 1968, the Political Bureau of the Central Committee of the PLA in a special meeting, would analyze the main problems in the field of education, aiming to further strengthen the Party's control over the entire education system.

According to the researcher Eriketa Kambo, the new reform that was being prepared was a continuation of the previously conceived, controlled, top-down reforms, but which further deepened the class character of education. Thus, the changes would take on a comprehensive character, in all school categories, including basic documentation, plans, programs and textbooks, which would undergo a radical "review" and "cleansing", so that the teachingeducational process developed in compliance with PLA policies. ${ }^{11}$

In order to realize these great changes, it was necessary for the main leading role to be played by the Party itself, thus putting in the background the Ministry of Education and Culture, which according to E. Hoxha, despite having trained teachers and pedagogues, did not completely fulfill the framework of Marxist-Leninist formation. ${ }^{12}$

On April 4, 1968, the Central Commission for Education was established, as a responsible political body, for studying, organizing, directing and controlling, taking appropriate measures for the further revolutionization of the school. Mehmet Shehu was the leader of the given institution. The Ministry of Education would be an assisting

\footnotetext{
${ }^{4}$ Eriketa Kambo, Shkolla Shqiptare në vitet 1060-1970, CAS, Institutes of History, Tiranë: 2014, p.54

${ }^{5}$ E.Kambo, Shkolla Shqiptare, citation, p.55

${ }^{6}$ Ibid, p.162

7 Ibid, p.81

8 Ibid, p.121

9 Ibid, p.123

${ }^{10}$ Historia e Popullit Shqiptar, citation, p.285

${ }^{11}$ E.Kambo, Shkolla Shqiptare, citation, p.262

12 Enver Hoxha, Vepra 37, 8 Nëntori, Tiranë: 1982, p.318-319
} 
structure, which would conduct studies and give opinions. On April 11, the National Education Activist gathered to pave the way for a "major popular discussion" on further revolutionization of the school. ${ }^{13}$

In the following months, through sophisticated ways and forms, the totalitarian state elaborated the thought in its own interest. Specialists or teachers, being used and manipulated, declared their participation in discussions of their own free will, were encouraged to write articles and express proposals, remarks, even if contradictory, as long as they did not contradict the party. Seen in the prism of the demands of the time, the school according to the concept of the PLA, should contribute to the preparation of sufficient and qualified employees and staff to work in various branches of economics and especially in the political sphere of social. The school also had to increase its role, to raise the educational level of the masses and especially the working class, to narrow the gap between physical and mental work, between village and city and finally for the defense of the homeland and socialism. In this prism, according to the directives of E. Hoxha, three main lines had to be taken into account: First, the issue of MarxismLeninism, which in school had to be studied separately as a science, but also through all other subjects. MarxismLeninism, as the main axis, had to be organically linked to all subjects. Second, in the frame of productive work as a revolutionary factor and ideological hardening of school youth. Third, in the preparation of school youth, in an organized manner, for the protection of the homeland. ${ }^{14}$

Under these conditions, the triangle "education - productive work - physical and military education" was influenced by the Marxist-Leninist ideological axis that was the basis of the whole teaching process. The connection of learning with production, of theory with practice, would represent the main way of connecting school with the economic, political and social life of the country. ${ }^{15}$

Plenum VIII of the Central Committee of the PLA defined the framework of the new education system. The 8-year school (elementary school) was further strengthened and consolidated as a "massive school unique to the general culture, compulsory, as the basic link of the Albanian education system. The age of enrollment to school would be 6 years old. Developments in 8-year general and compulsory education in urban and rural areas created conditions for the expansion and strengthening of the secondary education. The policies and structures developed at this stage would aim at a gradual transition to a diverse secondary education, to overcome both the "intellectual biases" in general secondary education and the narrow "practicalism" of the vocational one. As a result, state structures tended to channel the discussions into arguing the need to build a more flexible, diversified school system with a variety of part and full time upper secondary schools. ${ }^{16}$

At the center of the education policy for the upper secondary schools was the approximation of the knowledge provided by the technical schools with those of the general education. Basic subjects, in volume and quality had to be treated equally with those of other schools. This would lead to a non-unique but diverse secondary education for all as well as expanding opportunities for its extension. Before pursuing higher education, students would spend a preparatory year completing knowledge in general culture. ${ }^{17}$

The framework of the changes also affected the labelling of schools:"Gymnasium", "Technical School", "Polytechnic School", " Upper Secondary School of Arts ", which were replaced with "Upper Secondary schools" general, industrial, agricultural, construction, school of art etc. This aimed at breaking up with the tradition of the "old bourgeois school". 18

On December 24, 1969, the Council of Ministers presented to the People's Assembly the law "On the new education system" which would enter into force from January 1970. According to this law, the Albanian school would continue to give its contribution "for the preparation and education of the young man with a comprehensive communist formation, loyal to the end of the party affair, closely connected with the working people ". The essential change consisted in the construction of the new educational system "... on the basis of the organic unity of learning

${ }^{13}$ E.Kambo, Shkolla Shqiptare, citation, p.264-265

14 Enver Hoxha, Vepra 39, 8 Nëntori, Tiranë: 1983, p. 298

15 Mehmet Shehu, Mbi konkluzionet e diskutimit popullor, the magazine Arsimi Popullor, no.4, Tiranë: 1968, p.39

16 E.Kambo, Shkolla Shqiptare, citation, p.277-278

17 M.Shehu, Mbi konkluzionet e diskutimit popullor, citation, $p .48,58$

18 E.Kambo, Shkolla Shqiptare, citation, p.282 
with productive work and with physical and military education, giving absolute priority to the Marxist-Leninist ideological axis". ${ }^{19}$

The deepening of ideology was noticed both in the doubling of the number of hours and the quality of some special subjects. The course "Moral and political education" would be carried out in the last two grades of 8 -year school (lower secondary school), increasing the number of hours from 36 to 66 hours. A unique curriculum of the course "Initial Knowledge of Marxism-Leninism" would be implemented in all secondary schools, starting with the History of the ALP, further with the basic notions of political economy and dialectical and historical materialism. Thus, the establishment of a complete cycle of direct political subjects, starting from the lowest to the highest levels, and their treatment as "separate from the most important" subjects, further deepened the process of introducing MarxistLeninist ideology, in every cell of the educational learning process. ${ }^{20}$

Undoubtedly, the textbooks were also included in the changes, which according to the directives had to be reviewed and rewritten. The working groups that would be set up for these texts would include experts with Marxist-Leninist training and worldview who also were proficient in terms of their specialty and masters of pedagogical methods. ${ }^{21}$

Youth organizations operating in schools, oriented and led by the party, were subsidiary bodies for the communist education of school youth, acting on the basis of a regulation and their statute. By helping the school and the teachers for the realization of this education, they in the basic lines developed the activity in accordance with the rules of the school and the principle of its unique direction. ${ }^{22}$

The party leadership considered the teacher as an essential part of this process of revolutionization, as a result it would tend towards ways and means, which led to the total commitment of all teaching staff, to bring to the students his policies and beyond at all levels of the population. Thus, importance was given to increasing the scientific, professional and methodological level of the teachers. Specifically, attention was paid to the perfection of the methods that best served the communist education of the youth and in this context, the strengthening of the ideological struggle, which was the core of official policy at the time. ${ }^{23}$

And the last link of the education system, higher education, in all its activity would be influenced by the "revolutionary triangle of learning - productive work - physical and military education".

In addition to direct production work, students would go through all levels of physical and military preparation, ranging from basic training, discipline, and military life, to completing more complex activities. At the end of high school, the aim was to enable students to perform the task of a military specialist. ${ }^{24}$

The new education system, which was adopted in the early 1970s, had the following composition:

-Preschool education for children aged 3-5 years.

-8-year (lower secondary) education for children aged 6-13, full time primary education and special schools.

-Upper Secondary education: 4- year general secondary schools, 4- year vocational secondary schools: 1 and 2 year industrial, agricultural, art, pedagogical, medical, economic, commercial, lower technical schools, part or full time -Internships in production, one-year practice.

-Higher education included 3-5-6 year old high schools and 2 and 3 year pedagogical institutes, part or full time

-9- month internship in Production and 3 -month military training for students who had studied in the part time system.

-Postgraduate education included specialization and requalification courses based on higher education. ${ }^{25}$

The legal sanction of building a new education system with content and structure that better suited the policies of the communist state shifted the school's priorities towards a deeper mastery of the basic principles of communist education. The strengthening of direct political subjects and the description of the whole teaching-educational

19 Ligji nr.4024, date 24.12.1969, Mbi sistemin e ri arsimor, Official newspaper, no.10, Tiranë: 1969, p.112-113

20 E.Kambo, Shkolla Shqiptare, citation, p.291

$21 \mathrm{lbid}$, p.302

22 E.Kambo, Shkolla Shqiptare, citation, p.319

23 Ibid, p.349,354

24 Ibid, p.387,389

${ }^{25}$ Hajrullah Koliqi, Historia e Arsimit dhe e Mendimit Pedagogjik Shqiptar, Libri Shkollor, Prishtinë: 2002, p.451 
ISSN 2661-2666 (Online) International Scientific Journal Monte (ISJM) DOI: 10.33807/monte.20211835

Volume 4, (No).1 (2021): April

process from the ideological axis, deepened more and more the class character of the Albanian education. Thus, the emergence of the law paved the way for the implementation of the reform "On the further revolutionization of the school" which brought many changes in the Albanian education system in the second half of the twentieth century. Ideopolitical education was at the epicenter of the entire educational learning process. This damaged both the scientific formation of young people and the formation of their character. 


\section{Bibliography}

Historia e Popullit Shqiptar, vëllimi IV, Group of authors, Toena, Tiranë, 2008

Hoxha. Enver, Vepra 18, 8 Nëntori, Tiranë: 1970

Hoxha. Enver, Vepra 37, 8 Nëntori, Tiranë, 1982

Hoxha. Enver, Vepra 39, 8 Nëntori, Tiranë, 1983

Kambo. Enriketa, Shkolla Shqiptare në vitet 1960-1970, CAS, Institutes of History, Tiranë, 2014

Koliqi. Hajrullah, Historia e arsimit dhe e mendimit pedagogjik shqiptar, Libri Shkollor, Prishtinë: 2002

Ligji nr.4024, dt.24.12.1969, “Mbi sistemin e ri arsimor”, Official Newspaper, nr.10, Tiranë: 1969

Shehu. Mehmet, "Mbi konkluzionet e diskutimit popullor", the magazine Arsimi Popullor, no.4, Tiranë:1969

Uçi. Alfred, "Roli dhe rëndësia e kritikës dhe autokritikës", the magazine Rruga e Partisë, no 2, Tiranë: February 1955 